\title{
The Social Doctrine of Zeev Jabotinsky, from the Fathers of Zionism
}

\author{
David Schwartz \\ The Department of Political Science, Bar Ilan University, Ramat Gan, Israel \\ Email: dvd99@015.net.il
}

How to cite this paper: Schwartz, D. (2016). The Social Doctrine of Zeev Jabotinsky, from the Fathers of Zionism. Open Journal of Political Science, 6, 387-392.

http://dx.doi.org/10.4236/ojps.2016.64034

Received: August 22, 2016

Accepted: September 23, 2016

Published: September 26, 2016

Copyright (@) 2016 by author and Scientific Research Publishing Inc. This work is licensed under the Creative Commons Attribution International License (CC BY 4.0).

http://creativecommons.org/licenses/by/4.0/

(c) (i) Open Access

\begin{abstract}
Zeev Jabotinsky, in contrast to the conservative economic approach that characterizes the right parties around the world, in essence supports a social democratic approach in the economic dimension, at least in the stage of the establishment of the Jewish state that will be established. Jabotinsky considered the topic of the need to protect the person's individualism to be very important, since "every individual is a king" and he also supports the idea of the welfare state. The state has to give the individuals there basic needs, but the new Jew has to pay contribution to building the Hebrew new nation and new society. His approach was mixed of liberalism and nationalism, and he adopted the universal attitude of the famous Russian writer Tolstoy to the human suffer, and admired Garibaldi the leader that united Italy. After the second world war and the rise of the Fascists dictatorship of Germany and the communist revolution, Jabotinsky emphasized his belief in the values of liberalism like the American approach of Abram Linkolen that gave freedom to the slaves. Jabotinsky died in New York in the United States, the land of freedom and liberalism as refugee, far away from Russian culture that he was born to.
\end{abstract}

\section{Keywords}

Revisionist Movement, Distributive Justice, Social Heritage of the Bible, National Arbitration, Monism, Personal Autonomy

\section{Introduction}

Zeev Jabotinsky, lived from 1880 to 1940 and was one of the fathers of Zionism, but did not live to see the establishment of the State of Israel.

He established the Revisionist Movement in Zionism in 1925. He saw himself to be the continuation of the political Zionism of Herzl, which primarily addressed the political issue, namely, the demand to establish the Jewish State, so as to solve the troubles of 
the Jews of Eastern Europe (Bela, 1972).

Jabotinsky was influenced by the spirit of nationalism that prevailed in Europe of the 18th century. He was influenced by his Italian teachers and by the changes that occurred in the countries of Eastern Europe, in Russia, Poland and the Ukraine.

Jabotinsky was a partner in the discussions of the Helsinki Committee that discussed the situation of minorities in the territories of the Austro-Hungarian Empire. He supported the issue of lingual cultural autonomy among minorities in Russia, including for the Jews.

In addition, Jabotinksy addressed the general topic of distributive justice, namely, fairness, equality and division of resources, including in the national aspect regarding relations of Jews and Arabs in the land of Israel, as expressed in his famous article "The Iron Wall and the Arab Problem" and its continuation article "The Morality of the Iron Wall".

However, in addition to national aspects, he expressed himself in the social economic field, when he proposed to draw elements from the social heritage of the Bible, such as the Fallow Year and tithing. He also addressed in the youth movement he established, Beitar, five components: food, dress, healing, teaching, residence ${ }^{1}$. In other words, he referred to the person's scale of needs, which the country must provide for its citizens.

Jabotinsky considered the topic of the need to protect the person's individualism to be very important, since "every individual is a king".

Therefore, he objected to the monopoly in the economy of the General Workers' Union, which prevented fair competition. However, he proposed mandatory arbitration, by the State, primarily because of the desired "absorption regime", in his opinion. In other words, this is the situation of the absorption of mass immigration for the purpose of the bringing the immigrants to the Jewish State. After this stage of absorption, it is possible to return to full competition, to a normal situation of a free market.

In essence, there is in his doctrine a proposal for a social liberal welfare state, of course with the agreement that the political flag is the most important. Thus, Jabotinsky is in essence continuing in the path set forth by Herzl, the founder of the Zionist movement who supports a modern and national civil society.

Jabotinsky performs a separation between the stage prior to the establishment of the State, in which it is necessary to recruit concentrated and centralized resources for the founding of the Jewish State, which he sees as the most important thing, so as to solve the distress of the Jews in the Diaspora, who lacked a "national home", and the stage in which the Jewish State will be established and then there will be time to address the problems of internal social justice. He in essence proposes a type of Western Europe social democratic welfare state.

Jabotinsky believed that "every individual is a king" (Bilsky Ben Hur, 1988) and that the state's intervention in the individual's life must not be exaggerated. He believed that it is important to first strive for the establishment of the Jewish State, and thus he emphasized 'monism', singular focus, or in other words, the main effort for political action ${ }^{1}$ In Hebrew these five components are known as the five "mems", since the Hebrew letter "mem" begins each word (מזון, מלבוש, מרפא, מורה, מעון). 
of broad scope for the purpose of the establishment of the Jewish state and only afterwards the engagement in the areas of society and welfare (Shavit, 1978). Jabotinsky noted that the state when it would be established would need to allow the person living in it to have minimum conditions so he could live with dignity.

Jabotinsky, who was an anarchist in his youth, displayed a high degree of social sensitivity, but he rejected completely the Marxist solution of "workers of the world unite" and the proletariat revolution, since he strived first for a Renaissance, for national revival, through Zionism. Therefore, he searched for some of the social ideas according to the social ideas found in the Bible. In his opinion, the Biblical remedy for social problems is the jubilee year, according to Leviticus 25. "The fundamental difference between it and socialism is the difference between a method that comes to remedy the ills and a method that comes to promote the ills". The Bible preserves economic freedom, and thus Jabotinsky proposes according to it the remedies for economic distress: the jubilee year, the field corner commandment, the tithing commandment, and keeping the Sabbath.

The idea of the jubilee year enables the person who has become poor to recover his property, "The enslaved will become free, again equilibrium is restored, the game is begun anew, until a new revolution" (Jabotinsky, 1949: pp. 183-191).

Jabotinsky found in the Bible "laws of protection" (or in other words, laws that protect the employee). The welfare state depicts according to him a world in which the word "hunger" sounds like a tale from the olden days, a world in which no person must worry about widows and orphans, about lack of success, about a "decline" from a high economic level to a low economic level. This society creates for all a soft and warm 'platform', which enables the person to eat till he is filled and to rest and then to begin a new life. The source for all this will be two Hebrew words and each one with only three letters "Sabbath" and "Corner"2 (Jabotinsky, 1949).

Jabotinsky hoped that the gap between rich and poor would be reduced and he understood that the idea of the Jubilee required improvement. Thus, he wanted to assemble experts to translate the idea into operative terms.

\section{Main Tenets of the Social Approach: Influences of the Bible and the Principle of Monism}

Jabotinsky addressed the concept of "social redemption", which is not related to the question of the worker. It is necessary to give a person minimal conditions for the purpose of the filling of his needs, the 'elementary needs', which can be expressed concisely in the five components: food, residence clothing, teaching, healing (Jabotinsky, 1934). The state must provide them to its citizens.

Jabotinsky did not want a welfare state but wanted to give services to the entire population. It is enough that the person will announce that he is needy.

He did not see a potential danger in this proposal regarding the person's desire to work. "A person wants to work according to his nature. He has the drive to create new

${ }^{2}$ In Hebrew Sabbath is שבה and corner is פקה. 
things, and he is the strongest of all factors in the economy".

He proposed a "security net", which "will catch the person who has stumbled and will prevent him from a fall that would strongly impact him".

However, Jabotinsky noted that in essence it is necessary to adopt a policy of mandatory national arbitration in the field of work relations in the economy. In his opinion, a strike in the land of Israel, in the precarious situation of the construction of infrastructure, is unjust, since "the Jewish economy in the land of Israel is far from being stable. Our economy is fragile and has many obstacles on its path" (Jabotinsky, 1950).

"In the period of construction a war of class conflicts is not possible, rather only the compromise of these conflicts". Therefore, "the best method to determine whether a strike is justified or not is the method of arbitration. According to this method, a permanent non-party arbitration institution will decide in the situation of work conflicts, without causing harm to the economy by a strike".

Jabotinsky determined that after the establishment of the national arbitration court, the three forms of class dispute will be: shutdown (on the part of the employers), strike (on the part of employees), and shunning Jewish work. He further proposed "neutral bureaus of work in the city and community". In other words, he wanted to eliminate the employment offices operated by the General Workers' Union and transform them into state bureaus (as the situation is today).

At the same time, he objected to a "class war" and proposed establishing a "parliament of professions, which will have from the professional unions" (Jabotinsky, 1950), and not on the basis of employers and workers.

The national arbitration needs to function as long as the process of the solving of the demographic problem in the Land of Israel has not been completed, namely, until the Jewish majority in the land of Israel is created. "First of all, it is necessary to take into account one interest, the interest of the establishment of the State ... it is necessary to take into account only one factor, the development of Jewish settlement, the multiplicity of the places for the absorption of Jewish immigrants, so as to create a Jewish majority in the future state" (Katz, 1993).

This is, in essence, the doctrine of 'one miracle', his monism, which emphasizes the political activity as the crownpiece, when the social aspect is expressed only in the second stage of the creation of demographic and security facts.

Jabotinsky notes the place of the physical workforce would be taken in the future by "the spiritual force, the brain of the inventor, the producer, and the organizer". "What will be in another 25 years? The value of the pair of shoes that our grandchildren will wear will constitute the work of muscles perhaps no more than five percent (or one percent). In contrast, the spirit and the mind, the raw material and the method, will be $95 \%$ or $99 \% . "$

Jabotinsky criticized socialism in the identity it created between the problem of employed workers and the social problem. He saw the social problem, such as the problem of the poor, who do not belong necessarily to the working class and objected to the solutions proposed by the socialists: "They thought of the change of the entire economic 
construct, instead of thinking of one thing, which is the main thing: the destruction of poverty" (Jabotinsky, 1950).

Jabotinsky saw himself as a bourgeoisie: "I am a bourgeoisie, the son of a bourgeoisie, my father is a bourgeoisie, by the grace of God I am a bourgeoisie." He continued, "We are the bourgeoisie, the enemies of the police state, the harbingers of individualism" (Jabotinsky, 1927).

In his opinion, in a normal period, the person can believe in a number of ideals and promote each time one of them. The period of breakthrough is not normal. In this period the person must dedicate all of his energy to the Zionist ideal. It is necessary to build the Jewish State. "Most of the members of Beitar, who will immigrate to Israel, will serve as hired laborers. The pioneer can be a stonecutter, a teacher, an engineer, or a policeman, but first of all he is a pioneer".

Jabotinsky, in his famous article "Yes to Break" (Jabotinsky, 1932), called to break the monopoly of the General Workers Union over the market of hired labor and its dictating of the work relations in the Land of Israel. This course of action was not motivated by hatred but by his belief in democracy and work relations based on free will and the right of assembly.

Jabotinsky feared that the engagement in a class war supposedly would delay the revolution of the Zionist national movement. "Zionism is an independent ideal, it is beautiful, pure, clean, and moral, and therefore everything that delays it is immoral" (Jabotinsky, 1958).

Jabotinsky did not disqualify intensive engagement in problems of society and welfare, but only after the completion of the primary Zionist task, a Jewish State with a demographic majority. In his article "The Meaning of Adventurism" (Jabotinsky, 1948), he even preaches adventurism and original thinking, which changes according to the reality of the "captain" (the leader) (Jabotinsky, 1948: pp. 22-23). In his opinion, just like it is necessary to adjust to the winds of the sea, it is necessary for the leaders of Zionism to adjust themselves to the dynamic and political changes in the world.

\section{Conclusion}

The social thought of Jabotinsky was influenced by the social thinkers of the 18th and 19th centuries in Europe, such as the Austrian Karl Renner, or in his literary name Rudolph Springer, who on the one hand addressed personal autonomy that every individual has, and on the other hand stated that the State must provide the individual with his basic welfare conditions, so he has a decent existence (Hadari, 2013).

Despite Jabotinsky's reference to the importance of every individual person, he too wanted to create a "new person" who will serve the goals of the Zionist revolution. $\mathrm{He}$ was influenced by the "futurism" and the idea of the modern industrialized state. In contrast to what Avineri attempts to delineate as "integral nationalism", in essence with fascist tones (Avineri, 1980), and in contrast to the first biographer of Jabotinsky, which asserted that he was greatly influenced by Italian culture (Shechtman, 1959), Stanislawski (2001) maintained that Jabotinsky was a cosmopolitan and remained faithful to 
the ideas of individualism.

The social thought of Jabotinsky is a mergence, a combination between the desire to maintain the individual's autonomy and the desire for a welfare state, at least in the stage of the initial construction, the establishment of a country for Jews. When Jabotinsky was forced to separate himself from the socialist camp of the work movement, which became his rival, he emphasized bourgeoisie and liberal ideas in his doctrine.

He was a politician and such as he was not philosopher, he tried to find answers to the current problems and for the distress of the Jews especially in east Europe (Naor, 2013).

In the end of his political activity, he became the enemy of the social workers movement in Palestine, and he established his own Revisionist Labor as counterweight to them.

He died as a controversial leader. But in our days he has become the most admired leader in the state of Israel that he aspires to it.

\section{References}

Avineri, S. (1980). The Zionist Idea in Its Diversity (pp. 20-70). Tel Aviv: Am Oved Press.

Bela, M. (1972). The World of Jabotinsky: A Collection of His Statements and the Main Tenets of His Doctrine (p. 188). Tel Aviv: Defusim Press.

Bilsky Ben Hur, R. (1988). Every Individual Is a King (pp. 26-28). Tel Aviv: Zmora Beita N Press.

Hadari, G. (2013). A Liberal Intellectual or an Integral Nationalist? Descriptive Themes for the Intellectual Biography of ZeevJabotinsky. Israelis, 5, 5-86.

Jabotinsky, Z. (1927). We the Bourgeoisie. The North, May 8.

Jabotinsky, Z. (1932). Yes to Break, In E. Jabotinsky (Ed.), In a Storm (pp. 1-120). Jerusalem.

Jabotinsky, Z. (1934). The Social Redemption. In E. Jabotinsky (Ed.), Lists. Jerusalem.

Jabotinsky, Z. (1948). On the Way to a State (pp. 22-23). Jabotinsky, E: Jerusalem.

Jabotinsky, Z. (1948). The Meaning of Adventurism. Mail of the Day, August 5, 1937.

Jabotinsky, Z. (1949). Chapters in the Philosophy of the Bible. In E. Jabotinsky (Ed.), Nation and Society (pp. 183-191). Jerusalem.

Jabotinsky, Z. (1949). The Idea of the Jubilee. In E. Jabotinsky (Ed.), Nation and Society. Jerusalem.

Jabotinsky, Z. (1950). National Arbitration. In E. Jabotinsky (Ed.), Volume of Speeches, 1927 1940. Jerusalem.

Jabotinsky, Z. (1958). You Will Not Wear Shatnez (Mix of Fabrics). In E. Jabotinsky (Ed.), On the Way to a State (pp. 69-70). Jerusalem.

Katz, S. (1993). Biography of Zeev Jabotinsky. Tel Aviv: Dvir Press.

Naor, A. (2013). Zeev Jabotinsky-Liberal Nationalism (Vol. 1). Tel Aviv: The Jabotinsky Institute.

Shavit, Y. (1978). From Majority to State (pp. 4-55). Tel Aviv: Yariv Hadar Press.

Shechtman, Y. (1959). Zeev Jabotinsky: His Life. Tel Aviv: Karni Press.

Stanislawski, M. (2001). Zionism and The Fin de Siècle: Cosmopolitanism and Nationalism from Nordau to Jabotinsky. Berkeley: University of California Press. 
Submit or recommend next manuscript to SCIRP and we will provide best service for you:

Accepting pre-submission inquiries through Email, Facebook, LinkedIn, Twitter, etc. A wide selection of journals (inclusive of 9 subjects, more than 200 journals)

Providing 24-hour high-quality service

User-friendly online submission system

Fair and swift peer-review system

Efficient typesetting and proofreading procedure

Display of the result of downloads and visits, as well as the number of cited articles

Maximum dissemination of your research work

Submit your manuscript at: http://papersubmission.scirp.org/

Or contact ojps@scirp.org 